\title{
Heavy use of antibiotics in aquaculture: Emerging human and animal health problems - A review
}

\author{
Pathmalal M. Manage \\ Centre for Water Quality and Algae Research, Department of Zoology, University of \\ Sri Jayewardenepura, Nugegoda, Sri Lanka \\ Correspondence (pathmalal@sjp.ac.lk) \\ https://orcid.org/0000-0002-2014-2060
}

\begin{abstract}
Antibiotics have been extensively and effectively used in aquaculture due to accelerated growth of aquaculture and this has resulted in the development of serious health problems in aquaculture, other animals, and human. The use of a wide variety of antibiotics in large amounts, including non-biodegradable antibiotics, ensures that they remain in the aquatic environment for a long time. This has resulted; the emergence of antibiotic-resistant bacteria in the environments, an increase of antibiotic resistance in fish pathogens, transfer of these resistance determinants to bacteria and then land animals and finally become human pathogens along with alterations of the bacterial flora both in sediments and in the water column. Thus, the global efforts are needed to promote more judicious use of prophylactic antibiotics in aquaculture as accumulating evidence indicates that unrestricted use is detrimental to fish, terrestrial animals and human health.
\end{abstract}

Keywords: aquaculture, antibiotics resistance, environmental contamination, human health, risk management

\section{INTRODUCTION}

The aquaculture has rapidly grown in the worldwide as a major industry, providing not only economic income and high-quality food product, but also provides employment to hundreds of thousand skilled and unskilled workers. It has been predicted by 2050 , the total population of the planet will be around 9 billion. Therefore, aquaculture will have an important role in catering to the increased demand for protein food (Godfray et al. 2010). It has been identified that all animal production system has challenges associated with disease and the best way to solve this is often through effective management practices via management of stock, soil, water, nutrition, and environment (Ringo et al. 2014). Further, it has been identified that problems related to diseases and deterioration of environmental quality parameters often occurs and the final result may end up with serious economic losses (Balcazar et al. 2006). Hence, diseases in aquaculture systems are now considered as one of the critical limiting factors in this industry and special emphasis was given to shrimp aquaculture (Purivirojkul and Khidprasert 2009).

Many scientific studies have revealed that infectious diseases have remained as a significant problem in aquaculture system worldwide, and proper management approaches should be taken to mitigate against the effect of pathogens in farmed animals. Therefore, the methods of controlling diseases in aquaculture with management practices are given in Table 1 (Newaj-Fyzul et al. 2014). Recent studies to date have shown that several antimicrobial drugs including antibiotics have been approved and used in many countries to treat bacterial diseases in aquaculture and number of antibiotics are being used in aquaculture systems have exerted a very strong selection pressure towards resistance bacteria (Ringø et al. 2014).

The World Organization for Animal Health (WOAH) has developed standards in the Aquatic Animal Health Code (AAHC) on the responsible and prudent use of antimicrobial agents in aquatic animals. A list of Antimicrobials of Veterinary Importance has been published (World Organization for Animal Health 2015), which aims to optimize the balance between animal health 


\section{M.M. Pathmalal}

needs and public health considerations. To date, there is no harmonized system of surveillance is used worldwide and circulation of antimicrobial agents in aquaculture is widely available. In the world, antibacterial chemicals are being used in aquaculture to prevent and treat bacterial infections in fish and invertebrates (Cabello 2006; Cabello et al. 2013). For examples, in the United Kingdom sale of 2 tonnes of antibiotics are used in the production of fish (UK-VARSS 2014) where Canada and Norway permit use of oxytetracycline, florfenicol and quinolones for aquaculture (Cabello et al. 2013). The classic example is a usage of antibiotic quantity for
Salmon cultivation can vary as much as 175 -fold (e.g., $0.008-1.4 \mathrm{~kg}$ of antimicrobial) which is depended on country of the production (Cabello et al. 2013). The most abundant antibiotic quinolone (by mass) used in Norway for Salmon production was 821,997 tonnes in 2007), followed by oxolinic acid (681 kg in 2008), florfenicol, a synthetic derivative of chloramphenicol (166 kg in 2010) and oxytetracycline (23 kg in 2012) respectively (Burridge et al. 2010). Commonly used antibiotic classes in aquaculture sector, route of administration and their structures are given in Table 2.

Table 1. Methods of management practices of control diseases in aquaculture system in the world (Newaj-Fyzul et al. 2014)

\begin{tabular}{ll}
\hline \multicolumn{1}{c}{ Method } & \multicolumn{1}{c}{ Management practices with comments } \\
\hline $\begin{array}{l}\text { Animal husbandry/ } \\
\text { Management }\end{array}$ & Improved hygiene including sanitary disposal of dead animals; do not overstock and overfeed \\
$\begin{array}{l}\text { Movement restrictions } \\
\text { Dietary supplements }\end{array}$ & $\begin{array}{l}\text { Effective at preventing the spread of diseases; essential to have governmental support } \\
\text { Eaccine }\end{array}$ \\
$\begin{array}{l}\text { Availablive with compounds such as vitamin C } \\
\text { Probiotics }\end{array}$ & A wide range of probiotics has been considered for use in aquaculture \\
Biological control & Compounds that support the growth of probiotics; of increasing interest to aquaculture \\
& The application of inhibitory microorganisms often to water; may be effective but some concerns \\
over the fate of the inhibitors & \\
Antimicrobial & There are emotive issues in many countries about the non-medical use of medicinal compounds \\
\hline
\end{tabular}

ANTIBIOTIC USAGE IN SOUTH ASIAN COUNTRIES

Aquaculture already produces nearly half of the world's food fish and South Asia is the main countries which contribute more than $70 \%$ of the production of food fish (Bakar et al. 2013). Some South Asian Countries namely Vietnam, Thailand, Indonesia in the region has considerably developed their aquaculture sectors over recent decades, partly for the export market (Impens et al. 2003). Thus, the area is considered to be a hotspot of Antimicrobial Resistance (AMR). This represents a further risk of dissemination of AMR organisms and genes to consumers worldwide.

According to reported data, the use of antibiotics in aquaculture contributes equally to residues in the environment. Studies from Bangladesh, India, Indonesia, and Thailand have reported antibiotic residues in aquaculture products and aquaculture water (Impens et al. 2003; Bakar et al. 2013). Chloramphenicol was recorded in fish from Bangladesh ( $5 \mathrm{ng} / \mathrm{L})$ (Bakar et al. 2013) and in shrimps from India $(\sim 32 \mathrm{ng} / \mathrm{L})$ (Baker et al. 2013) and Indonesia ( $45 \mathrm{ng} / \mathrm{L})$ (Impens et al. 2003). In Thailand, erythromycin and tetracyclines were detected in aquaculture water up to $180 \mathrm{ng} / \mathrm{L}$ (Shimizu et al. 2013), whereas fluoroquinolones were detected in higher concentration (avg. $5130 \mathrm{ng} / \mathrm{L}$, $\max$ $46100 \mathrm{ng} / \mathrm{L})$ than aquaculture wastewater in Vietnam (avg. 235, max $1130 \mathrm{ng} / \mathrm{L}$ ) (Pham et al. 2015). In India, average peak water concentrations in aquaculture farms for Oxytetracycline (OTC) and Erythromycin were recorded as $49 \mu \mathrm{g} / \mathrm{L}$ and $1.6 \mu \mathrm{g} / \mathrm{L}$ (Koeypudsa et al. 2010) respectively while OTC were frequently detected in sediments with concentrations up to $6908 \mu \mathrm{g} / \mathrm{kg}$ (Koeypudsa et al. 2010).

When considered the Sri Lankan situation, despite the long history of antibiotic usage, 


\section{M.M. Pathmalal}

information regarding antibiotic production and usage patterns are severely limited due to the lack of coordinated and comprehensive monitoring and documenting efforts. Thus, this review paper aims to discuss environmental contamination status of some selected antibiotics in aquaculture farm effluents in Sri Lanka as well.

Table 2. Commonly used antibiotic classes in Aquaculture (Source: WHO 2005)

\begin{tabular}{|c|c|c|}
\hline Antibiotic agent (class) & $\begin{array}{c}\text { Route of administration in } \\
\text { aquaculture }\end{array}$ & Structure \\
\hline Oxytetracycline (tetracyclines) & Oral/bath/injection & \\
\hline Tetracycline (tetracyclines) & Oral/bath/injection & \\
\hline Amoxicillin (aminopenicillins) & Oral & \\
\hline Ampicillin (aminopenicillins) & Oral & \\
\hline Erythromycin (macrolides) & Oral/bath/injection & \\
\hline Sulphonamides (sulphonamides) & Oral & \\
\hline
\end{tabular}




\begin{tabular}{l|l}
\hline Oxolinic acid (Quinolones) & Oral \\
& \\
\hline MAJOR PATHWAYS OF \\
ENVIRONMENTAL CONTAMINATION \\
OF ANTIBIOTICS
\end{tabular}

Hygienic shortcomings in fish raising methods, including increased fish population densities, crowding of farming sites in coastal waters, lack of sanitary barriers and failure to isolate fish farming units with infected animals (Naylor and Burke 2005), have increased the possibility of the rapid spread of microbial infections in aquaculture.

\section{Antibiotic Resistance}

This scenario results in an augmented use of prophylactic antibiotics, often with the misplaced goal of forestalling these sanitary shortcomings (Grave et al. 1999; Sørum 2006) because, fish are given antibiotics as a component of their food, and occasionally in baths and injections (Sørum 2006; Gao et al. 2012). However, antibiotics can be metabolized after administration; but up to $80 \%$ of antibiotics administrated are excreted in urine or feces without complete decomposition (Muziasari et al. 2014). Therefore, it is possible that antibiotics can find their way into the aquatic environment from a variety of sources such as the excretion of animals and discharge from sewage waste treatment plants. Also, the unconsumed food and fish faeces containing antibiotics reach the sediment at the bottom of the raising pens; antibiotics are leached from the food and faeces and diffuse into the sediment and ultimately they can be washed away by currents to distant sites were recorded (Kerry et al. 1996; Hoa et al. 2011). Thus, the prophylactic and therapeutic use of antibiotics results in the occurrence of AntibioticResistant Bacteria (ARB) and Antibiotic Resistance Genes (ARGs) in the aquaculture environment (Ritter et al. 2008).

The most important issue of antibiotic release into the environment is the development of antibiotic resistance which has resulted in the reduction of therapeutic potential against human

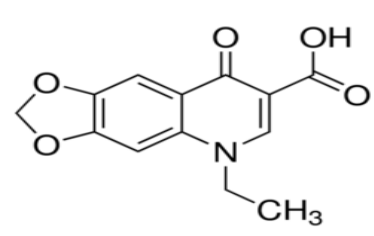

and animal pathogens (SCAN 2003; Liyanage and Manage 2016 a). Inappropriate and irrational use of antimicrobial agents provides favorable conditions for resistant microorganisms to emerge, spread and persist (Diwan et al. 2010). The greater the duration of exposure of the antibiotic has the greater the risk of the development of resistance, irrespective of the severity of the need for the antibiotic. Antibiotic resistance towards particular antibiotics becomes more common and a greater need for alternative treatments has arisen (Bush et al. 2011). Antibiotic resistance will develop in five different mechanisms was identified and explained so far as; alterations of the target site of the antibiotic, enzymatic inactivation of antibiotics, reduction of the inner and outer membrane permeability, flush out of the drug and using an alternative metabolic pathway.

\section{MECHANISMS OF RESISTANCE TO ANTIBIOTICS}

\section{Alteration of target site of the antibiotic (Mechanism 1)}

Connections of the antibiotic target areas are different. They can be various enzymes and ribosomes. Resistance associated with the alterations in the ribosomal target is the most frequently observed in macrolide antibiotics. Also, this is common for developing resistance to betalactams, quinolones, and tetracycline (Paterson et al. 2005; Bush et al. 2013).

\section{Enzymatic inactivation of antibiotics (Mechanism 2)}

Most of the gram positive and gram negative bacteria are synthesized enzymes that degrade antibiotics. In this group, beta-lactamases, aminoglycosides, modifying enzymes (acetylase, fosforiaz adenilaz) are potentially degraded betalactam antibiotics and continually increasing their number of which inactivates enzymes include 


\section{M.M. Pathmalal}

chloramphenicol and erythromycin (Paterson et al. 2005; Bush et al. 2013).

\section{Reduction of the inner and outer membrane permeability (Mechanism 3)}

This resistance decrease in drug uptake into the cell or quickly ejected from the active resistance of the pump systems. Reduction in permeability of the outer membrane may play an important role in resistance to quinolones and aminoglycosides (Thomas and Nielsen 2005).

Flush out of the drug (efflux pump) (Active Pump System) (Mechanism 4)

The production of complex bacterial machinery capable to extrude a toxic compound out of the cell can also result in antimicrobial resistance. Many classes of efflux pumps have been characterized in both gram-negative and gram-positive pathogens. This mechanism of resistance affects a wide range of antimicrobial classes including protein synthesis inhibitors, fluoroquinolones, $\quad \beta$-lactams, carbapenems and polymyxins (McMurry et al. 1980)

Using an alternative metabolic pathway (Mechanism 5)

Unlike some of the changes in the target bacteria, a new pathway for drug-susceptible eliminates the need to develop objective. In this way, resistance is seen among the sulfonamide and trimethoprim. Bacteria can gain property of getting ready folate from the environment instead of synthesizing folate (Jacoby et al. 2009). The discussed mechanisms are summarized in Figure 2.

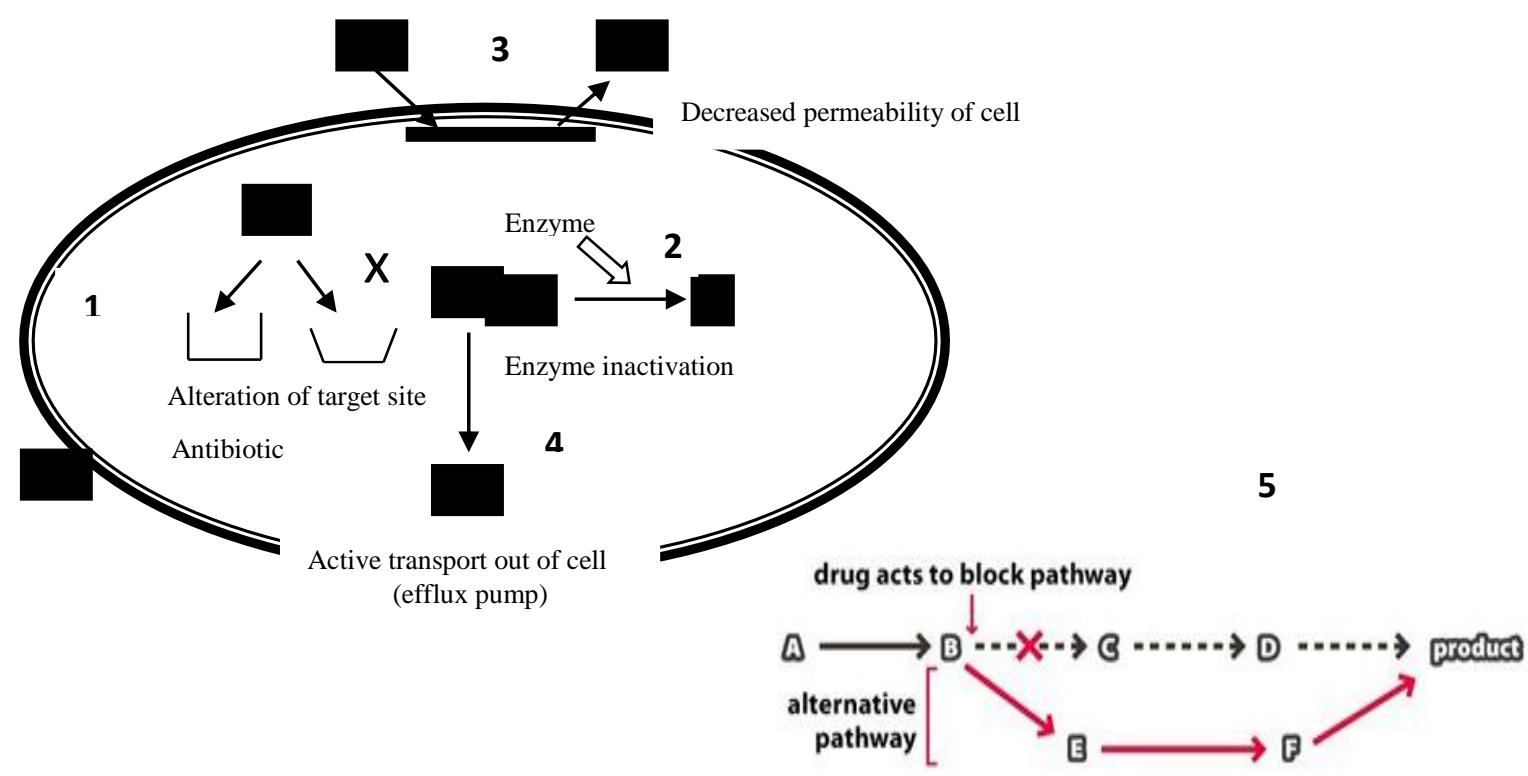

Figure 2. Antibiotic resistance mechanisms (1-alteration of target site; 2-enzyme inactivation; 3-reduction of inner and outer membrane permeability; 4- efflux pump; 5- Using an alternative metabolic pathway)

\section{Transfer of Resistance Genes}

When a bacterial cell divides, the chromosome of the bacterium is passed into its daughter cells (Vertical Transfer). But apart from this Vertical Transfer (VT), genetic information can also be passed between bacteria through processes known as Horizontal Gene Transfer (HGT). The three main processes of HGT are transformation, transduction, and conjugation. The nature of the genetic elements transferred is an important aspect of HGT. Major processes are; (a) transformation, the uptake of naked DNA via the cell wall, (b) transduction, viral-mediated (phage) gene transfer 
(c) conjugation, plasmid transfer from one DNA into the existing genome or plasmids (Lewin bacterium to another and the incorporation of that 1992).

a Bacterial transformation

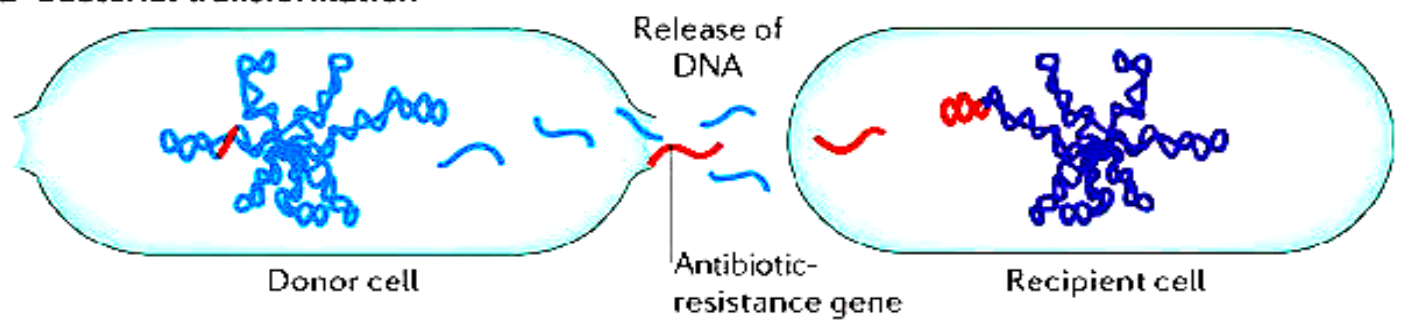

b Bacterial transduction

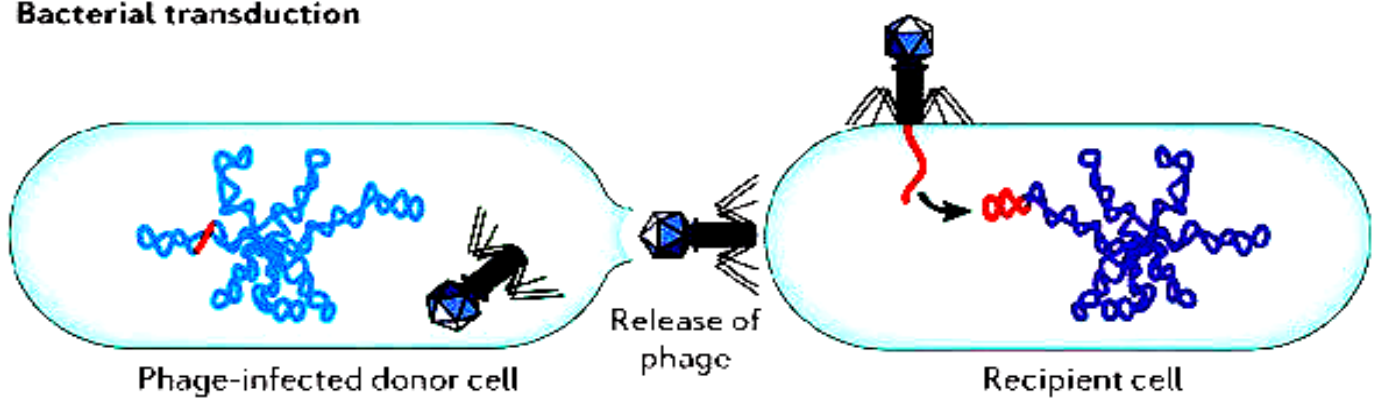

c Bacterial conjugation

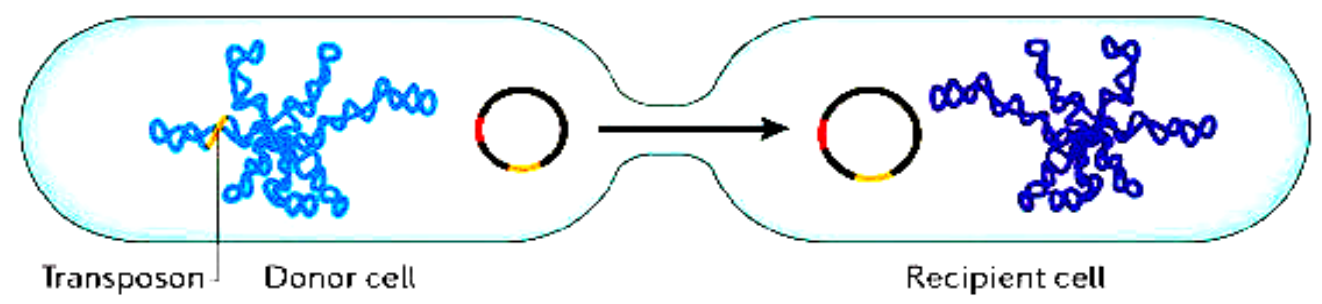

Figure 2. Major pathways in Horizontal Gene Transfer (HGT) (a- Bacterial transformation; b- Bacterial transduction; C- Bacterial conjugation) (Source: Nature Reviews - Microbiology 2006)

It is well documented that fish pathogens and other aquatic bacteria such as $A$. salmonicida, $A$. hydrophila, $C$. freundii, $V$. salmonicida, $F$. psychrophilum and $P$. fluorescens have developed resistance as a consequence of exposure to antibacterial agents (Sorum 2006). Acquired sulfonamide resistance in A. salmonicida, which cause disease in fish that inhibit temperature and cold climates, was reported in 1955 in the United States, and 1960s, multidrug-resistant bacteria strains were recorded in Japan (Suzuki et al. 2008). Since that time, the multidrug resistance of $A$. salmonicida has been described from many countries in various parts of the world, and transferable resistance plasmids were commonly recorded in these strains (Vincent et al. 2015).
Plasmids that carry multidrug-resistant determinants have been shown to be transferable to E.coli from A.salmonicida, A.hydrophila, V.cholerae, Shigella species, Salmonella species and E.coli (Suzuki et al. 2008; Sorum 2006). Genes coding for tetracycline resistance in fish farm bacteria and human clinical isolates in Japan has shown high similarity, suggesting that they were derived from the same source (Novais et al. 2012; Vincent et al. 2015). Furthermore, in laboratory experiments, transfer of tetracycline resistance from marine strains of Photobacterium species, Vibrio species, Aeromonas species and Pseudomonas species into E.coli by conjugation was recorded suggesting that transfer of resistance gene from marine bacteria to bacteria associated with the human gut is possible. Ultimately, 


\section{M.M. Pathmalal}

resistance genes in the aquatic environment may reach human pathogens and thereby add to the burden of antibiotic resistance in human medicine.

\section{DIRECT SPREAD OF ANTIBIOTIC RESISTANCE}

Aquatic environments can be a source of drugresistant bacteria that can be directly transmitted and cause infections in humans (Pham et al. 2015; Liyanage and Manage 2015). The spread to humans can happen through direct contact with water or aquatic organisms, through drinking water, through handling or consumption of aquaculture products (Suzuki et al. 2008). Direct spread from aquatic environments to humans can be involved human pathogens, such as $V$. cholera, V. vulnificus, Shigella species and Salmonella species or opportunistic pathogens, such as $A$. hydrophila, P. shigelloides, E. tarda and E. coli (Novais et al. 2012; Vincent et al. 2015). Thus, the occurrence of antimicrobial-resistant Salmonella species in aquatic environments is most likely attributable to contamination from human, animal or agriculture environments.

\section{AQUACULTURE IN SRI LANKA}

Sri Lanka does not have a tradition of aquaculture, despite the large freshwater and brackish water resources available in the country, there was virtually no aquaculture carried until the beginning of 1980 (Heenatigala and Fernando 2016). Since that time fish culture in seasonal village tanks, marine shrimp culture in coastal earthen ponds and live ornamental fish exports have reached commercial dimensions while other attempted methods such as fish culture in brackish water ponds, cage culture, mollusk and seaweed culture are yet to be developed (NAQDA 2015). At present, in many Asian countries including Sri Lanka, fish is the major protein diet of the local people (82\%) because of the consumption habit, health and its nutritional benefits (MFARD 2016). Annual aquaculture production in Sri Lanka has increased from $44300 \mathrm{Mt}$ and $334890 \mathrm{Mt}$ since 1999 to 2014 (NAQDA 2015). In the shrimp culture industry in Sri Lanka, financial losses due to the infectious diseases have become a major limiting factor in its development (Heenatigala and Fernando 2016). A major concern has been given to the viral infections of shrimps and as a result, their bacterial diseases have received less attention. Vibrio spp. are a part of the natural microflora of wild and cultured shrimps (Sinderman 1990) and the members of the family Vibrionaceae contribute to $60 \%$ of their total bacteria population (Simidu and Tsukamoto 1985). Vibrio bacteria are one of the main pathogenic organisms which cause high mortality in shrimp farming industry. The multitude of infections caused by bacteria belonging to the genus Vibrio is referred as vibriosis.

According to WHO, only 14 medicinal products including 7 antibiotic medicinal products (amoxicillin, florfenicol, flumequine, oxolinic acid, oxytetracycline $[\mathrm{OXY}]$, sarafloxacin [SARA], and sulfadiazine/trimethoprim) were authorized and approved for aquaculture (WHO 2014). Fluoroquinolones (FQ) and tetracyclines (TC), have also been approved as some additional antibiotics even they are being employed in human therapy (Cabello 2006; Heuer et al. 2009), are also widely used and effective veterinary antibiotics to prevent and treat fish diseases (FAO 2010). However, little information about the contamination status of antibiotics and ARGs are available in Sri Lanka. Therefore, monitoring studies of the antibiotics, ARB and ARGs in Sri Lanka aquaculture industry is necessary to develop safety and profitable aquaculture industry.

\section{Present status of antibiotic contaminations in aquaculture effluent water in Sri Lanka}

Effluent in aquaculture sites showed higher concentrations of antibiotics are belonging to tetracycline group compared to the other selected antibiotics tested (Figure 3). TET and OTC were detected at all sites except Dambulla, Muthupanthiya and Udappuwa, where detected OTC levels in shrimp hatcheries $(0.056 \pm 0.001$ $\mu \mathrm{g} / \mathrm{ml}-0.234 \pm 0.014 \mu \mathrm{g} / \mathrm{ml}$ ) were comparably higher than OTC levels in food fish farms $(0.008 \pm$ $0.012 \mu \mathrm{g} / \mathrm{ml}-0.221 \pm 0.012 \mu \mathrm{g} / \mathrm{ml})$ and ornamental fish farms $(0.009 \pm 0.011 \mu \mathrm{g} / \mathrm{ml}$ $0.031 \pm 0.005 \mu \mathrm{g} / \mathrm{ml}$ ) (Liyanage and Manage 2016b). Similarly, high TET levels were detected 


\section{M.M. Pathmalal}

in shrimp hatcheries $(0.012 \pm 0.019 \mu \mathrm{g} / \mathrm{ml}-0.112$ $\pm 0.017 \mu \mathrm{g} / \mathrm{ml})$ compared to ornamental $(0.001 \pm$ $0.002 \mu \mathrm{g} / \mathrm{ml}-0.002 \pm 0.031 \mu \mathrm{g} / \mathrm{ml}$ ) and food fish farms $(0.001 \pm 0.031 \mu \mathrm{g} / \mathrm{ml}-0.076 \pm 0.022 \mu \mathrm{g} / \mathrm{ml})$ respectively. The measured ERM concentrations in effluents of few aquaculture sites were in low level $(\sim 0.001 \mu \mathrm{g} / \mathrm{ml})$ and antibiotics group such as penicillin and sulfonamide were not detected in effluent samples (Liyanage and Manage 2016b).

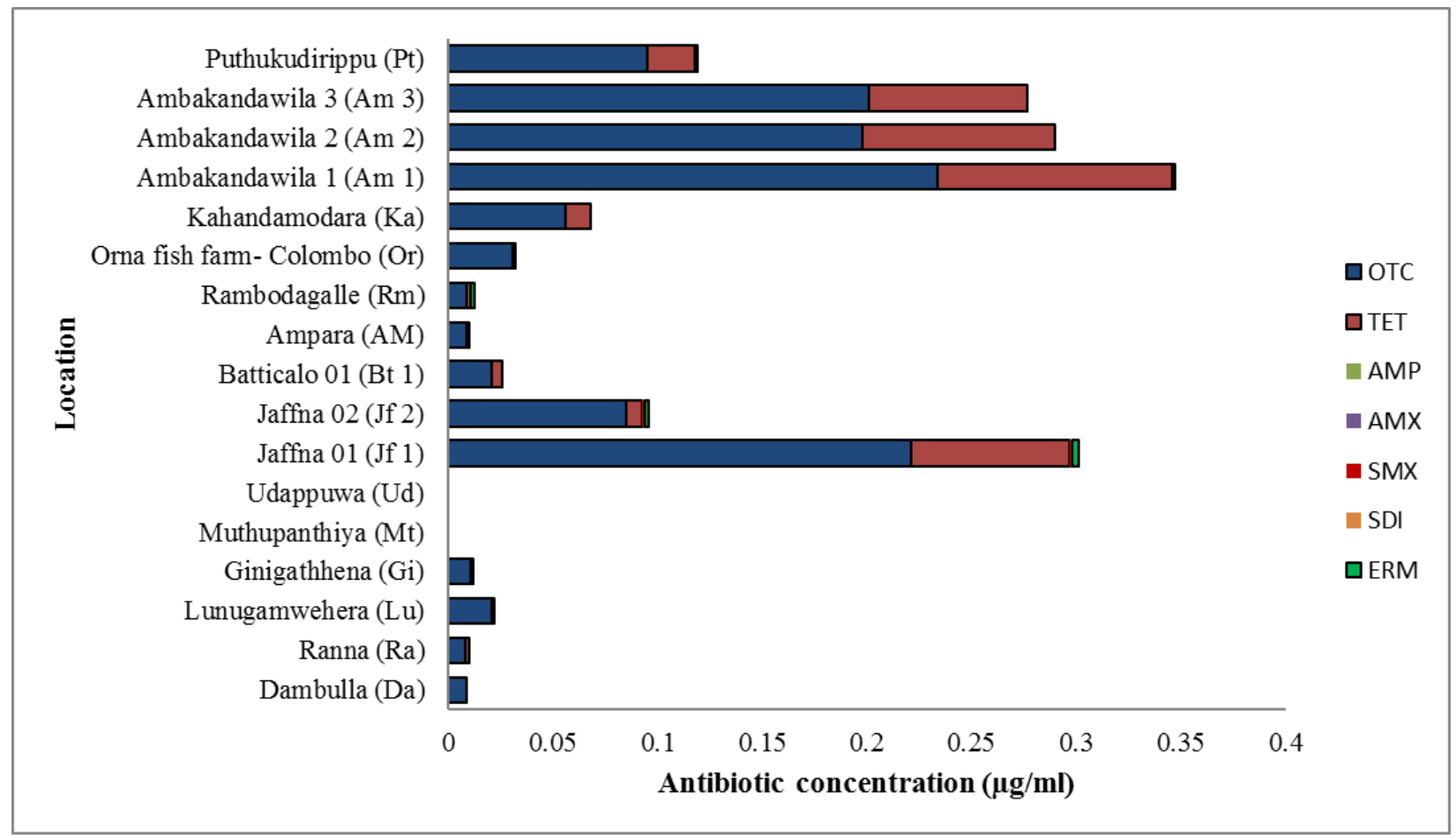

Figure 3. Antibiotic contaminations in aquaculture effluent water in Sri Lanka with studied aquaculture sites (OTC-Oxytetracycline; TET- Tetracycline; AMP- Ampicillin; AMX- Amoxicillin; SMXSulfamethoxazole; SDI- Sulfadiazine; ERM- Erythromycin)

In Sri Lanka, Bacillus sp., Acinetobacter sp., Achromabacter sp., Staphylococcus sp., Micrococcus sp. were identified as most abundant resistance genera for tetracycline and Oxytetracycline in aquaculture farms (Liyanage and Manage 2016b). The isolated strains except $B$. thurengiensis were recorded as pathogenic bacteria which causes different diseases such as fin rot, mouth rot, skin ulcers and abdominal swelling in fish and shrimp (Vincent et al. 2015). MIC values of OTCr bacteria ranged from 360 to $840 \mu \mathrm{g} / \mathrm{ml}$ and the highest was recorded for Pseudomonas aeriginosa whereas the lowest was for Bacillus sp. MIC values of TETr bacteria were varied from 320 $\mu \mathrm{g} / \mathrm{ml}$ to $780 \mathrm{ppm}$ whereas the highest MIC was recorded for the $S$. haemolyticus and the lowest was for the B. pumilus respectively (Liyanage and Manage 2016b). The tet (M) and tet (S) are well studied ribosomal protection protein gene, which is known to distribute widely in the aquatic environment, where tet( $\mathrm{A})$ and $\operatorname{tet}(\mathrm{B})$ are considered as genes efflux tetracycline from the cell. According to figure 4, 11 strains out of 16 isolates were positive for tet (M) and tet (A), suggesting that these genes were reserved in bacteria which were isolated from wastewater in aquaculture farms. In contrast, tet (S) (5/16) and tet (B) (4/16) were detected only a few TETr and OTCr isolates respectively (Liyanage et al. 2017).

The industrial development has been accompanied by some practices potentially damaging to human and animal health (Goldburg 


\section{M.M. Pathmalal}

and Naylor 2005; Naylor and Burke 2005) that include passing large amounts of veterinary drugs into the environment (Boxall et al. 2004).

This use has resulted in an increased antibiotic resistance of bacteria in the environment (Petersen et al. 2002; Alcaide et al. 2005; Liyanage and Manage, 2016a; Liyanage and Manage 2017). Moreover, this development has been accompanied by an increase of antibiotic resistance in fish

(a)

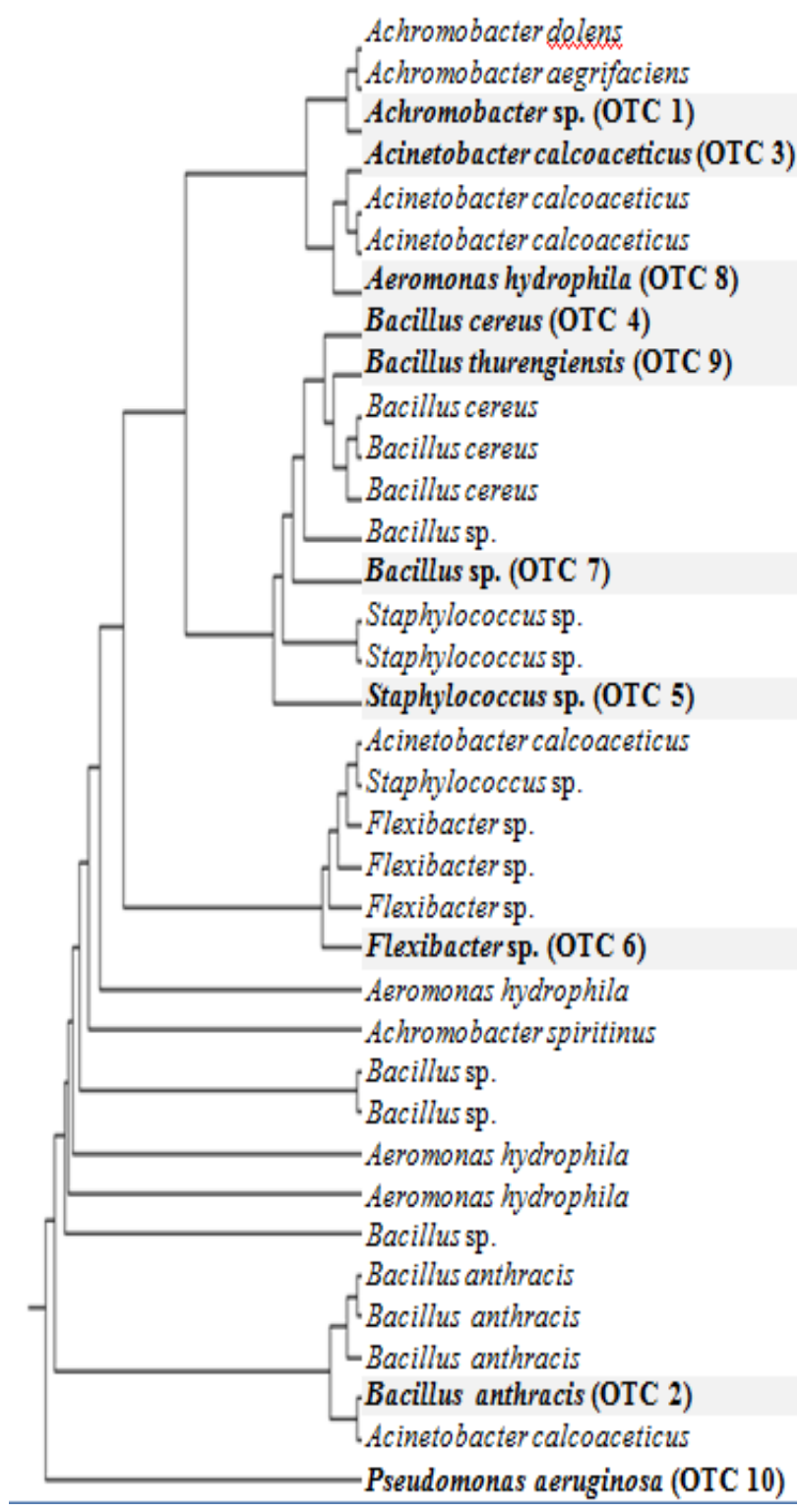

pathogens (Davies et al. 1999; Defoirdt et al. 2011) and increases the possibilities for passage not only of these antibiotic-resistant bacteria but also of their antibiotic resistance determinants to pathogenic bacteria and then to terrestrial animals and human beings (Sorum 2006; Liyanage and Manage 2014).

\begin{tabular}{|c|c|c|c|c|c|}
\hline \multirow{2}{*}{$\begin{array}{l}\text { Accession No. } \\
\text { HF } 586509\end{array}$} & \multirow[t]{3}{*}{ MIC } & tet $(M)$ & tet $(\mathrm{A})$ & tet (S) & tet (B) \\
\hline & & & & & \\
\hline \multicolumn{5}{|l|}{ HF586507 } & \\
\hline HF657890 & 760 & & & & \\
\hline KU567678 & 640 & & & & \\
\hline \multicolumn{6}{|l|}{ NR.042387 } \\
\hline \\
\hline \multicolumn{6}{|l|}{$\begin{array}{l}\text { EU.159482 } \\
\text { KL } 234156\end{array}$} \\
\hline KM 435657 & 410 & & & & \\
\hline KN 514297 & 420 & & & & \\
\hline \multicolumn{6}{|l|}{ FJ 982654} \\
\hline \multicolumn{6}{|l|}{ FJ 922659} \\
\hline \multicolumn{6}{|l|}{ FJ 982657} \\
\hline \multicolumn{6}{|l|}{ D1186353 } \\
\hline KM234561 & 360 & & & & \\
\hline \multicolumn{6}{|l|}{ KX 495499} \\
\hline \multicolumn{6}{|l|}{ HF947328 } \\
\hline EU 321541 & 580 & & & & \\
\hline \multicolumn{6}{|l|}{ AY 499112} \\
\hline \multicolumn{6}{|l|}{$\mathrm{KX} 458221$} \\
\hline \multicolumn{6}{|l|}{ FS 464023} \\
\hline \multicolumn{6}{|l|}{ KU 690365} \\
\hline \multicolumn{6}{|l|}{ KU 691844} \\
\hline KS 678976 & 540 & & & & \\
\hline \multicolumn{6}{|l|}{ AY 422734} \\
\hline \multicolumn{6}{|l|}{ HG 455018} \\
\hline \multicolumn{6}{|l|}{ HV 492636} \\
\hline \multicolumn{6}{|l|}{ HV 492635} \\
\hline \multicolumn{6}{|l|}{ AY 422736} \\
\hline \multicolumn{6}{|l|}{ AY 422737} \\
\hline \multicolumn{6}{|l|}{ E0 22555} \\
\hline \multicolumn{6}{|l|}{ AJ 516947} \\
\hline \multicolumn{6}{|l|}{ AJ 516943} \\
\hline \multicolumn{6}{|l|}{ AS 678425} \\
\hline L 42536 & 450 & & & & \\
\hline KJ 956437 & & & & & \\
\hline PR 617299 & 840 & & & & \\
\hline
\end{tabular}


M.M. Pathmalal

(b)

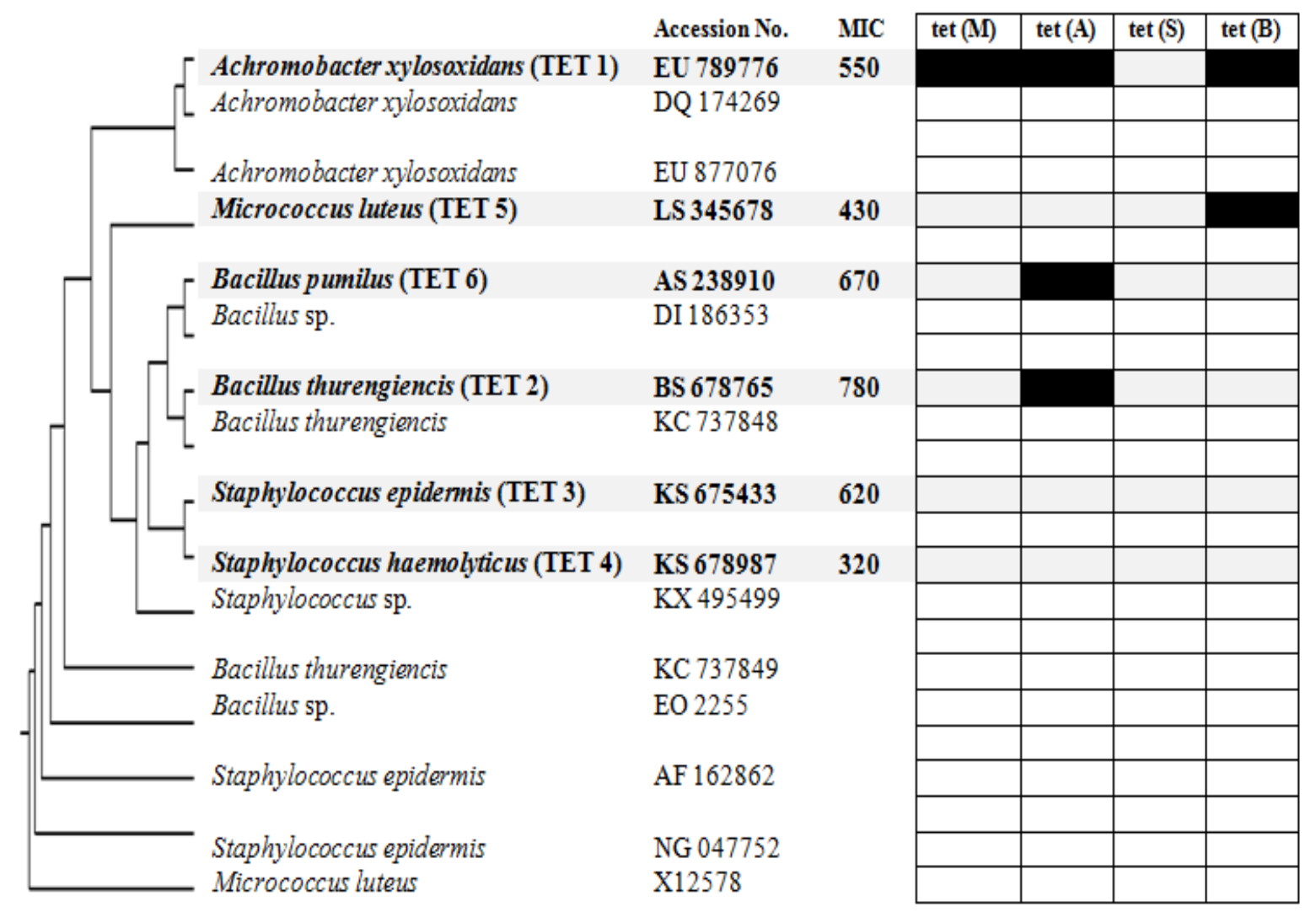

Figure 4. Phylogenetic affiliations with their phylogeny, Minimum Inhibition Concentration (MIC) values, and their resistance genes. (a) OTC resistance bacteria (OCTr); (b) TET resistance bacteria (TETr), The phylogeny was constructed by neighbor-joining method based on Mega 6/ Cluster W from alignment of 16s rRNA gene sequence comparison of antibiotic-resistant bacteria.

However, long-term use and misuse of antibiotics may cause alteration of microbial communities and the generation of drug-resistant strains of bacteria (Subasinghe et al. 2000).

\section{RISK FOR ANIMAL HEALTH}

The high detection frequency and concentration of TET are likely due to a large amount of TET used as feed additives and to control diseases in aquaculture sites. Thus the results of the study of Liyanage and Manage (2016b, 2017) agree with several previous studies, which show that TET is resistant to degradation and has sufficient hydrophobicity for transport into aquatic environment (Shah et al. 2014). The study demonstrates that aquaculture farms have been a reservoir of TET, ARB, and ARGs. The TETr bacteria; especially the possible opportunistic pathogens isolated from aquaculture environment and the presence TETr genes, implies an urgent need for constructing a monitoring system for antibiotic usage in aquaculture. Because ARGs and isolated ARB in farm water may lead to problems in the fish diseases and eventually to production losses at the fish farms. 


\section{M.M. Pathmalal}

\section{RISK FOR HUMAN HEALTH}

Antibacterial agents may disturb the microflora of human intestinal tract and increased risk for certain infections. When people taking an antibiotic for any reason, increased the risk for infections due to particular pathogens become resistant to that antibiotic (Pham et al. 2015). Also increased the frequency of treatment failure and increased the severity of infection as a result of antibiotic resistance and that may result in the prolonged duration of illness, increased the frequency of bloodstream infections, increased hospitalization (Kruse et al. 1994). Also for antibacterial resistant nontyphoid Salmonella serotypes and Campylobacter, increased morbidity or mortality has been demonstrated (Moges et al. 2014). It is reasonable to assume that the same phenomenon that has been demonstrated for Salmonella and Campylobacter species can occur with other drugresistant human pathogens, for which resistant may originate in aquaculture.

\section{ANTIBIOTIC USAGE AND FUTURE}

The antibiotic era began in the 1930s, with the discovery and isolation of bactericidal compounds made by actinomycetes fungi. Over the next few decades during what has been called the golden era of antibiotic drug discovery at least 65 antibiotics in nine classes were found and introduced into medical use. However, at present most of the antibiotics lose their effectiveness over time as antibiotic resistance evolves and spread. New antibiotics are more expensive and out of reach for many who need them, especially in low-andmiddle-income countries with a high burden of infectious diseases. New agents are not the most important tool in maintaining the global stock of antibiotic effectiveness. Conserving the effectiveness and complementary technologies are vital.

\section{RISK MANAGEMENT OPTIONS}

The most effective means to prevent and control the development and spread of antibacterial resistance is to reduce the use of antibiotics by reducing the need for antibacterial treatments
(Moges et al. 2014). A regulatory framework at the national level is needed for registration, approval, and control of the use of antibacterial agents in all countries in which antibacterial agents are used in aquatic animals. Production management should include stocking programs and management practices to avoid the introduction of pathogens and to prevent disease outbreaks and should include control measures to be implemented if the disease occurs. WHO estimated that by 2050 , antimicrobial resistance will be responsible for 4.7 million deaths in the Asia region (WHO 2015). In Sri Lanka developed the National Strategic Plan (NSP) 2017-2022 with the collaboration of WHO in 2016 (National Strategic Plan-2017-2022). The NSP is developed under five key strategies which are aligned with the strategic objectives of the Global Action Plan. Those strategies are; improve awareness and understanding of antimicrobial resistance through effective communication, strengthen the knowledge and evidence base through surveillance and research, Reduce the incidence of infection through effective sanitation, hygiene and infection prevention measures, optimize the use of antimicrobial medicines in human and animal health and prepare the economic case for sustainable investment and increase investment in new medicines, diagnostic tools, vaccines and other interventions. Further studies that provide clear evidence of the link between inappropriate antibiotic use in aquaculture, and antibiotic residues and antibiotic resistance in bacterial pathogens, are needed to develop the appropriate control strategies.

\section{CONCLUSIONS}

Use of antibiotics in aquaculture provides a selective pressure that creates reservoirs of drugresistant bacteria and transferable resistance genes in fish pathogens and other bacteria in the aquatic environment. From the reservoir in the aquaculture environment, some antibiotic-resistant pathogenic bacteria can be transferred to humans, but more importantly, resistance genes from bacteria in the aquatic environment can disseminate by horizontal gene transfer and reach human pathogens. The risk of horizontal gene transfer from fish pathogens and other bacteria in the aquatic environment to human pathogens has not been fully investigated, but it is 


\section{M.M. Pathmalal}

likely to be significant. Considering the rapid growth and importance of the aquaculture industry in many regions of the world and the widespread, intensive, and often unregulated use of antimicrobial agents in this area of animal production, efforts are needed to prevent the development and spread of antimicrobial resistance in aquaculture. These efforts should be focused on improvement of management routines, regulatory control of the use of antimicrobial agents, implementation of prudent use guidelines and monitoring of the use of antimicrobial agents and antimicrobial resistance.

\section{REFERENCES}

Alcaide, E., M.-D. Blasco and C. Esteve 2005. Occurrence of drug-resistant bacteria in two European eel farms. Applied Environmental Microbiology 71: 3348-3350.

DOI: 10.1128/AEM.71.6.3348-3350.2005

Balcázar, J.L., I. de Blas, I. Ruiz-Zarzuela, D. Cunningham, D. Vendrell and J.L. Muzquiz 2006. The role of probiotics in aquaculture. Veterinary Microbiology, 114 (3-4): 173-186. https://doi.org/10.1016/j.vetmic.2006.01.009

Boxall, A.B., L.A. Fogg, P.A. Blackwell, P. Kay, E.J. Pemberton, and A. Croxford 2004. Veterinary medicines in the environment. Reviews of Environmental Contamination and Toxicology 180: 1-91.

DOI: 10.1007/0-387-21729-0_1

Burridge, L., J.S. Weis, F. Cabello, J. Pizarro and K. Bostick 2010. Chemicaluse in salmon aquaculture: are view of current practices and possible environmental effects. Aquaculture 306: 7-23. DOI:10.1016/j.aquaculture.05.020

Bush K. 2013. Proliferation and significance of clinically relevant $\beta$-lactamases. Annals of the New York Academy of Sciences 1277: 84-90. doi: 10.1111/nyas.12023.

Bush, K., P. Courvalin, G. Dantas, J. Davies, et al. 2011. Tackling antibiotic resistance. Nature Reviews Microbiology 9: 894-896. DOI: 10.1038/nrmicro2693

Cabello, F.C. 2006. Heavy use of prophylactic antibiotics in aquaculture: a growing problem for human and animal health and for the environment. Environmental Microbiology 8: 1137-1144.

DOI:10.1111/j.1462-2920.2006.01054.X

Cabello, F.C., H.P. Godfrey, A. Tomova, L. Ivanova, H. Dölz, A. Millanao, et al. 2013. Antimicrobial use in aquaculture re-examined: its relevance to antimicrobial resistance and to animal and human health. Environmental Microbiology 15: 1917-1942.

DOI:10.1111/1462-2920.12134

Davies, J.E., M.C. Roberts, S.B. Levy, G.H. Miller, T.F. O'Brien and F.C. Tenover (eds) 1999. Antimicrobial resistance: An ecological perspective. (A report from the American Academy of Microbiology) Colloquium held 16-18 July 1999, San Juan, Puerto Rico. American Academy of Microbiology, Washington DC.

Defoirdt, T., P. Sorgeloos and P. Bossier 2011. Alternatives to antibiotics for the control of bacterial disease in aquaculture. Current Opinion in Microbiology 14(3): 251-258. https://doi.org/10.1016/j.mib.2011.03.004

Diwan, V., A.J. Tamhankar, R.K. Khandal, et al. 2010. Antibiotics and antibiotic-resistant bacteria in waters associated with a hospital in Ujjain, India. BMC Public Health 10: 414. https://doi.org/10.1186/1471-2458-10-414

Gao, P., D. Mao, Y. Luo, L. Wang, B. Xu and L. $\mathrm{Xu}$ 2012. Occurrence of sulfonamide and tetracycline-resistant bacteria and resistance genes in aquaculture environment. Water Research 46(7): 2355-2364. https://doi.org/10.1016/j.watres.2012.02.004

Godfray, H.C.J., J.R. Beddington, I.R. Crute, L. Haddad, D. Lawrence, J.F. Muir, J. Pretty, S. Robinson, S.M. Thomas, and C. Toulmin 2010. Food security: the challenge of feeding 9 billion people. Science 327(5967): 812-818. DOI: 10.1126/science. 1185383

Goldberg, R. and R. Naylor 2005. Future seascapes, fishing, and fish farming. Frontiers in Ecology and the Environment 3: 21-28.

Grave, K., E. Lingaas, M. Bangen, and M. Rønning 1999. Surveillance of the overall consumption of antibacterial drugs in humans, domestic animals and farmed fish in Norway in 1992 and 1996. Journal of Antimicrobial Chemotherapy 43: 243-252.

https://doi.org/10.1093/jac/43.2.243 


\section{M.M. Pathmalal}

Heenatigala P.P.M. and M.U.L. Fernando 2016. Occurrence of bacteria species responsible vibriosis in shrimp pond culture systems in Sri Lanka and assessment of the suitable control measures. Sri Lanka Journal of Aquatic Sciences 21(1): 1-17. http://doi.org/10.4038/sljas.v21i1.7481

Hoa, P.T.P., S. Managaki, N. Nakada, H. Takada, A. Shimizu, D.H. Anh, P.H. Viet and S. Suzuki 2011. Antibiotic contamination and occurrence of antibiotic-resistant bacteria in aquatic environments of northern Vietnam. Science of the Total Environment 409: 2894-2901. doi: 10.1016/j.scitotenv.2011.04.030.

Impens, S., W. Reybroeck, J. Vercammen, D. Courtheyn, S. Ooghe, K. De Wasch, and H. De Brabander 2003. Screening and confirmation of chloramphenicol in shrimp tissue using ELISA in combination with GC-MS ${ }^{2}$ and LC-MS2. Analytica Chimica Acta 483: 153-163.

Jacoby G.A. 2009. AmpC beta-lactamases. Clinical Microbiology Reviews 22(1): 161-82. doi: 10.1128/CMR.00036-08

Karunasagar I., R. Pai, G.R. Malathi, I. Karunasagar 1994. Mass mortality of Penaeus monodon larvae due to antibiotic-resistant Vibrio harveyi infection. Aquaculture 128: 203209. DOI: 10.1016/0044-8486(94)90309-3

Kerry, J., R. Coyne, D. Gilroy, M. Hiney and P. Smith 1996. Spatial distribution of oxytetracycline and elevated frequencies of oxytetracycline resistance in sediments beneath a marine salmon farm following oxytetracycline therapy. Aquaculture 145: 31-39. https://doi.org/10.1016/S0044-8486(96)01353-1

Kruse, H. and H. Sørum 1994. Transfer of multiresistance plasmids between bacteria of diverse origin in natural microenvironments. Applied Environmental Microbiology 60: 4015-4021.

Lewin, C.S. 1992. Mechanisms of resistance development in aquatic microorganisms. pp. 288-301. In: Michel, C. and D.J. Alderman, (eds), Chemotherapy in Aquaculture: from Theory to Reality. Office International des Epizooties, Paris, France.

Li, X.-Z. 2005. Quinolone resistance in bacteria: emphasis on plasmid-mediated mechanisms. International Journal of Antimicrobial Agents 25: 453-463.
DOI: 10.1016/j.ijantimicag.2005.04.002

Liyanage, G.Y. and P.M. Manage 2014. Quantification of oxytetracycline and ampicillin in two wastewater discharging points in Colombo, Sri Lanka. Proceedings of the 1st Environment and Natural Resources International Conference (ENRIC2014), 6-7 November 2014, The Sukosol hotel, Bangkok, Thailand. pp. 193-198.

Liyanage, G.Y. and P.M. Manage 2015. Presence of tetracycline and oxytetracycline resistant bacteria and resistant genes in effluent water of Zoological Garden, Sri Lanka. Proceedings of the 11th International Academic Conference on Development in Science and Technology (IACDST-2015), 19 December 2015, Singapore. pp. 11-14.

Liyanage, G.Y. and P.M. Manage 2016a. Occurrence, fate and ecological risk of antibiotics in hospital effluent water and sediments in Sri Lanka. International Journal of Agriculture and Environmental Research 4: 909-935.

Liyanage, G.Y. and P.M. Manage 2016b. Occurrence and distribution of tetracycline resistance determinants and their pollution status in the aquaculture environment of Sri Lanka. Proceedings of the $3^{\text {rd }}$ International Conference on Multidisciplinary Approaches, University of Sri Jayawardenepura, Nugegoda. $8 \mathrm{p}$.

Liyanage, G.Y. and P.M. Manage 2017. Risk of prophylactic antibiotics in livestock and poultry farms; a growing problem for human and animal health. Pharmaceutical Journal of Sri Lanka 7(1): 13-22. http://doi.org/10.4038/pjsl.v7i0.16

Liyanage, G.Y., A. De Alwis and P.M. Manage 2017. Detection of tetracycline resistance genes in isolated bacteria from aquaculture sites in Sri Lanka, Proceedings of the $4^{\text {th }}$ International Conference on Multidisciplinary Approaches, University of Sri Jayawardenepura, Nugegoda. $162 \mathrm{p}$.

McMurry L.M., R.E. Petrucci Jr. and S.B. Levy 1980. Active efflux of tetracycline encoded by four genetically different tetracycline resistance determinants in Escherichia coli. PNAS, Proceedings of the National Academy of 


\section{M.M. Pathmalal}

Sciences of the United States of America. 77: 3974-3977.

Ministry of Fisheries and Aquatic Resources Development 2016. Available from http://www.fisheries.gov.lk/statistics.html

Moges F., M. Endris, Y. Belyhun and W. Worku 2014. Isolation and characterization of multiple drugs resistant bacterial pathogens from waste water in hospital and non-hospital environments, Northwest Ethiopia. BMC Research Notes 7: 215. DOI: 10.1186/17560500-7-215

Moriarty, D.J.W. 1999. Disease control in shrimp aquaculture with probiotic bacteria. In: Microbial Biosystems: New Frontiers. Proceedings of the $8^{\text {th }}$ International Symposium on Microbial Ecology Bell C.R., M. Brylinsky and P. Johnson-Green (eds) Atlantic Canada Society for Microbial Ecology, Halifax, Canada.

National Aquaculture Development Authority of Sri Lanka (NAQDA) 2015. Available from http://www.naqda.gov.lk/ [accessed 21 December 2016].

National Strategic Plan-2017-2022. Available from http://www.searo.who.int/srilanka/areas/antimic robial_resistance/national_strategy_amr.pdf?ua $=1$

Nature Reviews - Microbiology 2006. https://images.nature.com/full/natureassets/nrmicro/journal/v4/n1/images/nrmicro13 25-f2.jpg

Naylor, R. and M. Burke 2005. Aquaculture and ocean resources: raising tigers of the sea. Annual Review of Environment and Resources 30: $185-218$.

https://doi.org/10.1146/annurev.energy.30.0818 04.121034

Newaj-Fyzul, A., A.H. Al-Harbi and B. Austin 2014. Review: Developments in the use of probiotics for disease control in aquaculture. Aquaculture 431: 1-11.

http://dx.doi.org/10.1016/j.aquaculture.2013.08. 026

Novais, C., A.R. Freitas, E. Silveira, F. Baquero, L. Peixe, A.P. Roberts and T.M. Coque 2012. Different genetic supports for the $\operatorname{tet}(\mathrm{S})$ gene in enterococci. Antimicrobial Agents and Chemotherapy 56(11): 6014-6018.

DOI: 10.1128/AAC.00758-12
OIE - World Organization for Animal Health 2015. OIE List of antimicrobial agents of veterinary importance. OIE - World Organization for Animal Health, Paris.

Otta, S.K., I. Karunasagar and I. Karunasagar 2001. Bacteriological study of shrimp Penaeus monodon Fabricius hatcheries in India. Journal of Applied Ichthyology 17: 59-63.

DOI: 10.1046/j.1439-0426.2001.00249.x

Paterson, D.L. and R.A. Bonomo 2005. Extendedspectrum beta-lactamases: a clinical update. Clinical Microbiology Reviews 18(4): 657-686. DOI: 10.1128/CMR.18.4.657-686.2005

Petersen, A., J.S. Andersen, T. Kaewmak, T. Somsiri and A. Dalsgaard 2002. Impact of integrated fish farming on antimicrobial resistance in a pond environment. Applied Environmental Microbiology 68: 6036-6042. doi: 10.1128/AEM.68.12.6036-6042.2002

Pham, D.K., J. Chu, N.T. Do, F. Brose, G. Degand, P. Delahaut and M.L. Scippo 2015. Monitoring antibiotic use and residue in freshwater aquaculture for domestic use in Vietnam. EcoHealth 12(3): 480-489. https://doi.org/10.1007/ s10393-014-1006-z

Purivirojkul, W. and S. Khidprasert 2009. Diseases and parasites on cultured fairy shrimps, Branchinella thailandensis and Streptocephaluss irindhornae. In: Proceeding of Asian Pacific Aquaculture 2009, 3-6 November 2009, Kuala Lumpur, Malaysia. 444 p

Ring $\varnothing$, E., R.E. Olsen, I. Jensen, J. Romero and H.L. Lauzon 2014. Application of vaccines and dietary supplements in aquaculture: possibilities and challenges. Reviews in Fish Biology and Fisheries 24(4): 1005-1032. https://doi.org/10.1007/s11160-014-9361-y

SCAN 2003. The opinion of the scientific committee on animal nutrition on the criteria for assessing the safety of microorganisms' resistant to antibiotics of human clinical and veterinary importance. European Commission Health and Consumer Protection DirectorateGeneral, Belgium.

Shah, S.Q., F.C. Cabello, T.M. L'Abée-Lund, A. Tomova, H.P. Godfrey, A.H. Buschmann and H. Sørum 2014. Antimicrobial resistance and antimicrobial resistance genes in marine bacteria from salmon aquaculture and 


\section{M.M. Pathmalal}

non-aquaculture sites. Environmental Microbiology 16(5): 1310-1320.

DOI: $10.1111 / 1462-2920.12421$

Shimizu A., H. Takada, T. Koike et al. 2013. Ubiquitous occurrence of sulfonamides in tropical Asian waters. Science of the Total Environment 358: 108-115.

DOI: 10.1016/j.scitotenv.2013.02.027

Simidu, V. and K. Tsukamoto 1985. Habitat segregation and biochemical activities of marine members of the family Vibrionaceae. Applied and Environmental Microbiology 105: 781-790.

Sindermann, C.J. 1990. Principal Diseases of Marine Fish and Shellfish. Volume 2. 2nd Edition. Academic Press, New York.

Sørum, H. (2006) Antimicrobial drug resistance in fish pathogens. In: Antimicrobial Resistance in Bacteria of Animal Origin. Aarestrup, F.M. (ed.). American Society for Microbiology Press, Washington DC, USA pp. 213-238.

Subasinghe, R.P., U. Barg and A. Tacon 2000. Chemicals in Asian aquaculture: Need, usage, issues and challenges. 1-5 pp. In: J.R. Authur, C.R. LavillaPitogo, R.P. Subasinghe (eds) Proceeding of the Meeting on the Use of Chemicals in Aquaculture in Asia, 20-22 May 1996. SEAFDEC, Tigbauna, Iloilo.

Suzuki, S., T. Kobayashi, F. Suchiro, B.C. Tuyen and T.S. Tana 2008. High Occurrence rate of tetracycline resistant bacteria and TC resistance gene relates to microbial diversity in the sediment of Mekong river mail waterway. Microbes and Environment 23: 149-152. DOI: 10.1264/jsme2.23.149

Thomas, C.M. and K.M. Nielsen 2005. Mechanisms of, and barriers to, horizontal gene transfer between bacteria. Nature Reviews Microbiology 3(9): 711-721.

DOI: $10.1038 /$ nrmicro1234

UK-VARSS 2014. UK Veterinary Antibiotic Resistance and Sales Surveillance Report. Veterinary Medicines Directorate, Surrey, U.K.

Vincent, A.T., K.H. Tanaka, M.V. Trudel, M. Frenette, N. Derome and S.J. Charette 2015. Draft genome sequences of two Aeromonas salmonicida subsp. salmonicida isolates harboring plasmids conferring antibiotic resistance. FEMS Microbiology Letters 362(4): 1-4. DOI: 10.1093/femsle/fnv002
WHO 2005. Critically important antibacterial agents for human medicine; for risk management strategies of nonhuman use. Report of a WHO working group consultation, Canberra, Australia, 15-18 February 2005. World Health Organization, Geneva, Switzerland.

WHO 2014. Antimicrobial resistance: Global report on surveillance. Health Organization, Geneva, Switzerland.

WHO 2015. Global action plan on antimicrobial resistance. Health Organization, Geneva, Switzerland. http://www.who.int/drugresistance/global_actio n_plan/en/. 